\title{
Correction to: The Mitochondria-Targeted Methylglyoxal Sequestering Compound, MitoGamide, Is Cardioprotective in the Diabetic Heart
}

\author{
Mitchel Tate ${ }^{1,2} \cdot$ Gavin C. Higgins $^{2,3}$. Miles J. De Blasio ${ }^{1} \cdot$ Runa Lindblom $^{2,3} \cdot$ Darnel Prakoso $^{1} \cdot$ Minh Deo ${ }^{1}$. \\ Helen Kiriazis ${ }^{4} \cdot$ Min Park ${ }^{5} \cdot$ Carlos D. Baeza-Garza ${ }^{5}$. Stuart T. Caldwell ${ }^{6} \cdot$ Richard C. Hartley $^{6} \cdot$ Thomas Krieg $^{5}$. \\ Michael P. Murphy ${ }^{5,7}$ • Melinda T. Coughlan ${ }^{2,3} \cdot$ Rebecca H. Ritchie ${ }^{1,2}$
}

Published online: 15 February 2020

(C) The Author(s) 2020

Correction to: Cardiovascular Drugs and Therapy (2019) https://doi.org/10.1007/s10557-019-06914-9The article "The Mitochondria-Targeted Methylglyoxal Sequestering Compound, MitoGamide, Is Cardioprotective in the Diabetic Heart" written by Mitchel Tate, Gavin C. Higgins, Miles J. De Blasio, Runa Lindblom, Darnel Prakoso, Minh Deo, Helen Kiriazis, Min Park, Carlos D. Baeza-Garza, Stuart T. Caldwell, Richard C. Hartley, Thomas Krieg, Michael P. Murphy, Melinda T. Coughlan, and Rebecca H. Ritchie was originally published Online First without Open Access. After publication, the author decided to opt for Open Choice and to make the article an Open Access publication. Therefore, the copyright of the article has been changed to (C) The Author(s) 2019 and the article is forthwith distributed under the terms of

The online version of the original article can be found at https://doi.org/ 10.1007/s10557-019-06914-9

Rebecca H. Ritchie

Rebecca.Ritchie@baker.edu.au

1 Heart Failure Pharmacology, Baker Heart and Diabetes Institute, Melbourne, VIC, Australia

2 Department of Diabetes, Monash University, Melbourne, VIC, Australia

3 JDRF Danielle AlbertiMemorial Centre for Diabetic Complications, Diabetic Complications Division,, Baker Heart and Diabetes Institute, Melbourne, Australia

4 Experimental Cardiology, Baker Heart and Diabetes Institute, Melbourne, VIC, Australia

5 Department of Medicine, University of Cambridge, Cambridge, Biomedical Campus, Cambridge, UK

6 WestCHEM School of Chemistry, University of Glasgow, G12 18QQ, Glasgow, UK

7 MRC Mitochondrial Biology Unit, University of Cambridge, Cambridge Biomedical Campus, Cambridge CB2 0XY, UK the Creative Commons Attribution 4.0 International License (http://creativecommons.org/licenses/by/4.0/), which permits use, duplication, adaptation, distribution, and reproduction in any medium or format, as long as you give appropriate credit to the original author(s) and the source, provide a link to the Creative Commons license, and indicate if changes were made.

The original article has been corrected.

Open Access This article is distributed under the terms of the Creative Commons Attribution 4.0 International License (http://creativecommons.org/licenses/by/4.0/), which permits unrestricted use, distribution, and reproduction in any medium, provided you give appropriate credit to the original author(s) and the source, provide a link to the Creative Commons license, and indicate if changes were made. The images or other third party material in this article are included in the article's Creative Commons licence, unless indicated otherwise in a credit line to the material. If material is not included in the article's Creative Commons licence and your intended use is not permitted by statutory regulation or exceeds the permitted use, you will need to obtain permission directly from the copyright holder. To view a copy of this licence, visit http://creativecommons. org/licenses/by/4.0/.

Publisher's Note Springer Nature remains neutral with regard to jurisdictional claims in published maps and institutional affiliations. 